\title{
New arylhydrazonothiazolidin-5-one disperse dyes for dyeing polyester fibers
}

\author{
Mohamed A. Metwally, ${ }^{1, *}$ Mohamed E. Khalifa ${ }^{2}$, Ehab A. Attia ${ }^{1}$ and Fathy A. Amer ${ }^{1}$ \\ ${ }^{1}$ University of Mansoura, Faculty of Science, Department of Chemistry, Mansoura, Egypt \\ ${ }^{2}$ Chemical Laboratory of Misr Beida Dyers Co., Alexandria, Egypt \\ ${ }^{*}$ Corresponding author: \\ Mansoura University, Mohamed A. Metwally, Department of Chemistry, Faculty of Science, Mnasoura, Egypt, \\ e-mail: mamegs@mans.edu.eg
}

\begin{abstract}
A series of new thiazolidin-5-one disperse dyes was synthesized from the reactions of 2-substituted 3phenylthiazolidinones with various aryldiazonium chlorides. The synthesized dyes were characterized by UV-visible absorption, IR, NMR and MS spectroscopy. The dyes gave orange to reddish-violet shades with very good depth on polyester fibers. The dyed fabrics show moderate to good fastness to light and very good to excellent fastness to washing and perspiration. Also, the assessment of color coordinates was discussed.
\end{abstract}

Keywords: Thiazolidin-5-one, Diazonium salts, Azo coupling, Disperse dyes, Polyester fibers, Fastness properties, Color properties

\section{INTRODUCTION}

For some time an effort has been made to replace certain anthraquinone disperse dyes by azo dyes, often derived from coupling of diazonium salts with heterocyclic compounds. Especially useful in this respect are the dyes derived from 2-aminothiazoles and 2-pyridones as coupling components. These sulfur and/or nitrogen heterocyclic azo dyes provide bright strong shades that range from yellow, orange, red, and blue to green colors.

In the light of the considerable biological activity ${ }^{\mathbf{1}-5}$, the excellent dyeing properties associated with the thiazolidinone derivatives, and in continuation of the previous work ${ }^{6-8}$ on the synthesis of heterocyclic azo disperse dyes for dyeing polyester fibers, the present work describes the synthesis of several new arylhydrazonothiazolidin-5-one dyes and their applications as azo-disperse dyes for dyeing polyester fibers.

\section{EXPERIMENTAL}

\section{Materials and instrumentation}

Microanalyses of the elements: carbon and hydrogen were determined at Microanalytical Laboratories, Faculty of Science, Mansoura, Cairo and Alexandria Universities. All melting points are in degree centigrade and are uncorrected. Infrared spectra were recorded on a Perkin Elmer 14 spectrophotometer using potassium bromide Waffer technique. ${ }^{1} \mathrm{H}$ NMR spectra were measured on a Bruker WP 300 in $\mathrm{CDCl}_{3}$, DMSO or $\mathrm{CF}_{3} \mathrm{COOD}$ as a solvent, using TMS as an internal standard. Mass spectra were recorded on a Finnigan MAT 212 instrument. The substrate used for dyeing (100\% polyester fiber) was kindly provided by Misr Beida Dyers Company, Alexandria, Egypt, a product of Misr for synthetic Fibers Company, Kafr El-Dawar, Egypt. All applications, fastness properties and color measurements of the dyes were studied in Laboratories and Research sector in Misr Beida Dyers company, Alexandria, Egypt. The colorimetric measurements for the dyed polyester fibers were carried out using a reflectance spectrophotometer (GretagMacbeth CE 7000a). Fastness to washing was carried out using the automatic launder Rotadyer (sponsored by the British
Standard Institute - Society of Dyers and Colourists, fastness to perspiration was assessed according to the test sponsored by the (BSS), fastness to rubbing was carried out according to the standard method of testing (BSS) using Crockmeter of Electric Hungarian FD-17 type, fastness to sublimation was carried out using the Electric Japanese Thermotester T-10 type and fastness to light was carried out using the "Weather-o-meter" (Atlas Electric Devices Co. USA), AATCC standard test method.

\section{Synthesis of 2-substituted- 3-pheny-thiazolidin-5-ones 3-5}

To a cooled suspension of the finely ground potassium hydroxide $(0.01 \mathrm{~mol})$ in dimethylformamide $(25 \mathrm{ml})$, the active methylene compound $\mathbf{1}(0.01 \mathrm{~mol})$ was added and subsequently phenyl isothiocyanate $(0.01 \mathrm{~mol})$. The mixture was stirred at room temperature for 12 hours, treated with chloroacetyl chloride $(0.012 \mathrm{~mol})$ and left to stand at room temperature for 12 hours. The reaction mixture was then triturated with cold water $(100 \mathrm{ml})$ and few drops of dilute hydrochloric acid were added (till $\mathrm{pH}=$ 7). The solid precipitated was collected by filtration, washed several times with water and crystallized from ethanol-DMF mixture (2:1).

2-Cyano-2-(5-oxo-3-phenylthiazolidin-2ylidene)acetamide (3):

Yield: $78 \%$; m.p.: $>265^{\circ} \mathrm{C}$; IR $(\mathrm{KBr}) \vee\left(\mathrm{cm}^{-1}\right): 3425$, 3170 (NH2), $2194(\mathrm{CN}), 1665$ (CO amide), 1731 (CO ring). ${ }^{1} \mathrm{H} \mathrm{NMR}\left(\mathrm{CDCl}_{3}\right) \delta(\mathrm{ppm}): 4.5(\mathrm{~s}, 2 \mathrm{H}, \mathrm{CH} 2), 7.2-$ $7.7(\mathrm{~m}, 5 \mathrm{H}, \mathrm{Ph}), 9.0-9.1\left(\mathrm{~s}, 2 \mathrm{H}, \mathrm{NH}_{2}\right)$. Anal. calcd. for $\mathrm{C}_{12} \mathrm{H}_{9} \mathrm{~N}_{3} \mathrm{O}_{2} \mathrm{~S}$ : C, 55.59; H, 3.50; $\mathrm{N}, 16.21$. Found: $\mathrm{C}$, 55.53; H, 3.41; N, 16.09 .

N-Benzothiazol-2-yl-2-cyano-2-(5-oxo-3-phenylthiazolidin2-ylidene)acetamide (4):

Yield: $88 \%$; m.p.: $200^{\circ} \mathrm{C}$; IR $(\mathrm{KBr}) \vee\left(\mathrm{cm}^{-1}\right): 3428$ (NH), $2201(\mathrm{CN}), 1662$ (CO amide), 1734 (CO ring). ${ }^{1} \mathrm{H}$ NMR (DMSO) $\delta(\mathrm{ppm}): 4.2\left(\mathrm{~s}, 2 \mathrm{H}, \mathrm{CH}_{2}\right), 7.1-7.6(\mathrm{~m}$, $10 \mathrm{H}, 2 \mathrm{Ph}), 8.2(\mathrm{~s}, 1 \mathrm{H}, \mathrm{CH}=\mathrm{N}), 10.4(\mathrm{~s}, 1 \mathrm{H}, \mathrm{NH})$. Anal. calcd. for $\mathrm{C}_{19} \mathrm{H}_{14} \mathrm{~N}_{4} \mathrm{O}_{2} \mathrm{~S}$ : C, 62.97; H, 3.89; N, 15.46 . Found: C, 62.88; H, 3.79; N, 15.52 .

$N^{\prime}$-Benzylidene-2-cyano-2-(5-oxo-3-phenylthiazolidin-2ylidene)acetohydrazide (5)

Yield: $79 \%$; m.p.: $>265^{\circ} \mathrm{C}$; IR $(\mathrm{KBr}) \vee\left(\mathrm{cm}^{-1}\right): 3149$ (NH), $2203 \mathrm{~cm}^{-1}$ (CN), 1675 (CO amide), 1752 (CO ring). ${ }^{1} \mathrm{H}$ NMR (DMSO) $\delta$ (ppm): 4.2 (s, 2H, CH2), 7.0- 
7.7 (m, 9H, Ar-H), 10.2 (s, 1H, NH). Anal. calcd. for $\mathrm{C}_{19} \mathrm{H}_{12} \mathrm{~N}_{4} \mathrm{O}_{2} \mathrm{~S}_{2}$ : C, 58.15; H, 3.08; $\mathrm{N}, 14.28$. Found: $\mathrm{C}$, 58.21; H, 3.14; N, 14.33.

Synthesis of 2-substituted4-arylazo-3-phenylthiazolidin-5ones 6-8

The aryl diazonium chloride was prepared by the addition of a cold aqueous sodium nitrite solution $(0.7 \mathrm{gm}$ in $\left.10 \mathrm{ml} \mathrm{H} \mathrm{H}_{2} \mathrm{O}\right)$ to a cold suspension of aromatic amine $(0.01$ $\mathrm{mol})$ in concentrated $\mathrm{HCl}(3 \mathrm{ml})$ with stirring.

To a cold solution of the thiazolidin-5-ones 3-4 and/or $5,(0.01 \mathrm{~mol})$ in $10 \mathrm{ml}$ pyridine, a cold aqueous solution of aryl diazonium chloride $(0.01 \mathrm{~mol})$ was added dropwise with stirring. The reaction mixture was allowed to stand in cold for 2 hours, diluted with water and the solid obtained was filtered. The products were recrystallised from ethanol-DMF mixture $(2: 1)$ to give the corresponding 4-arylazothiazolidin-5-ones 6-8, respectively. The physical and spectroscopic data of compounds 6-8 are listed in Table 1.

\section{Synthesis of bishydrazono dyes 9 and 10}

A cold aqueous sodium nitrite solution (1.4 gm in 15 $\mathrm{ml} \mathrm{H}_{2} \mathrm{O}$ ) was added to a cold suspension of $p$-phenylenediamine and/or benzidine $(0.01 \mathrm{~mol})$ in concentrated $\mathrm{HCl}(6 \mathrm{ml})$ with stirring to give the aryl diazonium chloride. To a cold solution $3(0.01 \mathrm{~mol})$ in pyridine, a cold aqueous solution from the corresponding aryl diazonium chloride $(0.01 \mathrm{~mol})$ was added dropwise with stirring. The reaction mixture was allowed to stand in cold for 2 hours, diluted with water and then filtered, washed with water and the solid was filtered and recrystallised from ethanol-DMF mixture (1:1). The physical and spectroscopic data of compounds 9 and 10 are listed in Table 1.

\section{Dyeing and fastness determinations}

Dyeing of polyester fibers
Preparation of dye dispersion: The required amount of the dye (2\% shade) was dissolved in acetone and added dropwise with stirring to a solution of Setamol WS (0.5 -1.5), an anionic dispersing agent of BASF (sodium salt of a condensation product of naphthalene sulfonic acid and formaldehyde). The dye was precipitated in a fine dispersion ready for use in dyeing after the evaporation of the solvent by warming.

Dyeing procedure: The dye bath (1:20, good to dye liquor ratio) in a sealed stainless steel dye pots of $250 \mathrm{ml}$ capacity in "Galvanin-Marino VI-Italy" dyeing machine. Additional dispersing agent $(0.5-1.0 \mathrm{~g} / \mathrm{l})$ was added and the $\mathrm{pH}$ of the bath adjusted to 5.5 using glacial acetic acid. Dyeing carried out by raising the dye bath temperature from 20 to $130^{\circ} \mathrm{C}$ at a rate of $3^{\circ} \mathrm{C} / \mathrm{min}$ and holding at this temperature for $60 \mathrm{~min}$ before rapidly cooling to $50^{\circ} \mathrm{C}$ at $9.9^{\circ} \mathrm{C} / \mathrm{min}$. The dyed fibers were then rinsed with cold water, reduction-cleared using sodium hydroxide $(2 \mathrm{~g} / \mathrm{l})$ and sodium hydrosulphite $(1 \mathrm{~g} / \mathrm{l})$ and soaped with $2 \%$ nonionic detergent and ammonia $(\mathrm{pH} 8.5)$ at $50^{\circ} \mathrm{C}$ for 30 minutes to improve washing fastness.

\section{Fastness properties}

The color fastness of dyeing was evaluated using the standard method $\mathbf{9 1 0}$ and given in Table 3. The fastness to light, sublimation and perspiration was assessed in accordance with AATCC-15 (1985). The rubbing fastness test was carried out with a crockmeter (Atlas) in accordance with AATCC-88 (1988) and the wash fastness test in accordance with IS: 765-1979.

\section{RESULTS AND DISCUSSION}

\section{Dyestuff synthesis}

The base promoted nucleophilic addition of the cyanoacetamides $\mathbf{1}$ to equimolar amount of phenyl isothiocyanate in DMF containing potassium hydroxide afforded the corresponding non-isolable intermediate<smiles></smiles>

1

2

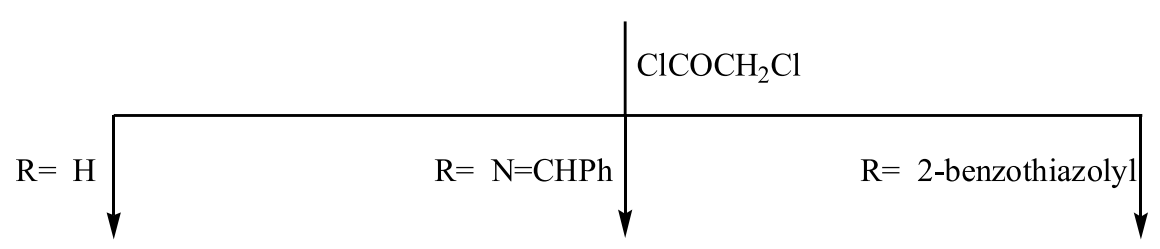<smiles>N#C/C(C(N)=O)=C1\SC(=O)CN1c1ccccc1</smiles>

3<smiles>N#C/C(C(=O)NN=Cc1ccccc1)=C1\SC(=O)CN1c1ccccc1</smiles>

4<smiles>N#CC(C(=O)Nc1nc2ccccc2s1)=C1SC(=O)CN1c1ccccc1</smiles>

5

Scheme 1. 
potassium sulphide salt $\mathbf{2}$. Heterocyclization of $\mathbf{2}$ was achieved in-situ by the reaction with chloroacetyl chloride to furnish the corresponding 3-phenyl-2-substituted-3phenyl-thiazolidin-5-ones 3-5 (scheme 1). The chemical structures of compounds $\mathbf{3}, \mathbf{4}$ and 5 were confirmed by analytical and spectral data including the IR and ${ }^{1} \mathrm{H}$ NMR spectroscopy.

Coupling of compounds 3-5 with different aromatic diazonium chlorides afforded twenty one new disperse dyes of the corresponding compounds 6-8, respectively (scheme 2). The structures of $\mathbf{6 - 8}$ were confirmed by their elemental analyses and various spectroscopic techniques. The IR spectra of 6-8 indicated the presence of $\mathrm{CN}$ groups $\left(2187-2197 \mathrm{~cm}^{-1}\right)$. They also revealed bands at $1722-$ 1729 and $1663-1668 \mathrm{~cm}^{-1}$ regions corresponding to the amide and the ring carbonyl groups, respectively. The ${ }^{1} \mathrm{H}$ NMR spectra support the hydrazonic rather than the azo forms in the tautomeric mixture. For example, the ${ }^{1} \mathrm{H}$ NMR spectrum of $6 \mathbf{e}$ showed a singlet at $11.0 \mathrm{ppm}$ due to the hydrazono proton $(\mathrm{C}=\mathrm{N}-\mathrm{NH})$. It also showed a singlet at $\delta 3.8$ due to the methoxy protons and a multiplet at 6.9-7.9 ppm region due to the aromatic and $\mathrm{NH}_{2}$ protons. The structure of $\mathbf{7 a}$ was also confirmed by mass spectroscopy and showed a molecular ion peak at $\mathrm{m} / \mathrm{z}=$ $466(54 \%)$.

To explore the importance of the chromophoric group, a new series of bisazo disperse dyes of the type 9 was synthesized by the coupling of tetrazotized $p$-phenylenediamine with two mole equivalents of 6-8. The structures 9 were confirmed by elemental analyses, IR and MS spectral data. The mass spectrum of 9a showed a molecular ion peak at $m / z=648(35 \%)$.

In addition, when the tetrazotized benzidine was allowed to couple with the highly functionalized thiazolidin5-ones 6-8, the corresponding bishydrazono derivatives 10a-c were obtained in good yield. The structures of $\mathbf{1 0}$ were established on the basis of their elemental analysis and spectral data (IR and MS).

It is clear that the appearance of a carbonyl absorption at $1722-1733 \mathrm{~cm}^{-1}$ region in the IR spectra of compounds 6-10 favors the hydrazono structures rather than the possible azo structures ${ }^{\mathbf{1 0}, \mathbf{1 1}}$.

\section{Absorption spectral characteristics}

The visible absorption data for the synthesized dyes were measured in chloroform and are listed in Table 2. The absorption maxima of the synthesized dyes ranged from 408 to $524 \mathrm{~nm}$. Within the series of azo dyes investigated, the relation between the shift observed in the absorption maxima, and polar characteristics of substituent, may be summarized as follows:

1. The introduction of an electrondonating group in the para position in the arylhydrazono moiety gives a bathochromic shift relative to the unsubstituted compound.<smiles>CCCCCCCCCN/N=C1/C(=O)S/C(=C(\C#N)C(N)=O)N1c1ccccc1</smiles>

6<smiles>N#C/C(C(=O)N/N=C/c1ccccc1)=C1\SC(=O)/C(=N/N=C/c2ccccc2)N1c1ccccc1</smiles>

7<smiles>CCCCCCCCCCCN/N=C1/C(=O)SC(=C(C#N)C(=O)Nc2nc3ccccc3s2)N1c1ccccc1</smiles>

8
a: $\mathrm{Ar}=\mathrm{C}_{6} \mathrm{H}_{5}$
b: $\mathrm{Ar}=p-\mathrm{MeC}_{6} \mathrm{H}_{4}$
c: $\mathrm{Ar}=o-\mathrm{MeOC}_{6} \mathrm{H}_{4}$
d: $\mathrm{Ar}=m-\mathrm{MeOC}_{6} \mathrm{H}_{4}$
e: $\mathrm{Ar}=p-\mathrm{MeOC}_{6} \mathrm{H}_{4}$
f: $\mathrm{Ar}=p-\mathrm{O}_{2} \mathrm{NC}_{6} \mathrm{H}_{4}$
g: $A r=p-\mathrm{BrC}_{6} \mathrm{H}_{4}$

Scheme 2.<smiles>[R]NC(=O)/C(C#N)=C1/SC(=O)/C(=N\Nc2ccc(N/N=C3\C(=O)S/C(=C(\C#N)C(=O)N[R])N3c3ccccc3)cc2)N1c1ccccc1</smiles>

a: $\mathrm{R}=\mathrm{H}$

b: $\mathrm{R}=\mathrm{N}=\mathrm{CHPh}$

c: $\mathrm{R}=2$-benzothiazolyl 
Table 1. Characterization data of the synthesized azo dyes 6-10

\begin{tabular}{|c|c|c|c|c|c|c|c|c|c|}
\hline \multirow[t]{2}{*}{ Dye } & \multirow[t]{2}{*}{ Appearance } & \multirow[t]{2}{*}{ Molecular formula } & \multirow[t]{2}{*}{ M.Wt. } & \multirow{2}{*}{$\begin{array}{c}\text { Yield } \\
(\%)\end{array}$} & \multirow{2}{*}{$\begin{array}{l}\mathrm{Mp} \\
\left({ }^{\circ} \mathrm{C}\right)\end{array}$} & \multirow{2}{*}{$\begin{array}{c}\mathrm{IR} \\
\gamma\left(\mathrm{cm}^{-1}\right)\end{array}$} & \multicolumn{3}{|c|}{$\begin{array}{l}\text { Elemental analysis: } \\
\text { Calc. (found) }\end{array}$} \\
\hline & & & & & & & C & $\mathrm{H}$ & $\mathrm{N}$ \\
\hline $6 a$ & Yellow & $\mathrm{C}_{18} \mathrm{H}_{13} \mathrm{~N}_{5} \mathrm{O}_{2} \mathrm{~S}$ & 363.39 & 84 & $>265$ & $\begin{array}{c}3456,3266,3346,2187 \\
1664,1724\end{array}$ & $\begin{array}{c}59.49 \\
(59.54) \\
\end{array}$ & $\begin{array}{c}3.61 \\
(3.52)\end{array}$ & $\begin{array}{c}19.27 \\
(19.36)\end{array}$ \\
\hline $6 b$ & Orange & $\mathrm{C}_{19} \mathrm{H}_{15} \mathrm{~N}_{5} \mathrm{O}_{2} \mathrm{~S}$ & 377.42 & 89 & $>265$ & $\begin{array}{c}3431,3262,3368,2194 \\
16681728\end{array}$ & $\begin{array}{l}71.85 \\
(71.71)\end{array}$ & $\begin{array}{c}5.24 \\
(5.39)\end{array}$ & $\begin{array}{c}14.57 \\
(14.63)\end{array}$ \\
\hline $6 c$ & Brown & $\mathrm{C}_{19} \mathrm{H}_{15} \mathrm{~N}_{5} \mathrm{O}_{3} \mathrm{~S}$ & 393.42 & 72 & 174 & $\begin{array}{c}3423,3188,3336,2193 \\
1672,1725\end{array}$ & $\begin{array}{l}71.85 \\
(71.79) \\
\end{array}$ & $\begin{array}{c}5.24 \\
(5.21)\end{array}$ & $\begin{array}{c}14.57 \\
(14.66) \\
\end{array}$ \\
\hline $6 d$ & Brown & $\mathrm{C}_{19} \mathrm{H}_{15} \mathrm{~N}_{5} \mathrm{O}_{3} \mathrm{~S}$ & 393.42 & 75 & 168 & $\begin{array}{c}3418,3211,3331,2194 \\
1668,1724\end{array}$ & $\begin{array}{c}71.85 \\
(71.71) \\
\end{array}$ & $\begin{array}{c}5.24 \\
(5.23) \\
\end{array}$ & $\begin{array}{c}14.57 \\
(14.64) \\
\end{array}$ \\
\hline $6 e$ & Brown & $\mathrm{C}_{19} \mathrm{H}_{15} \mathrm{~N}_{5} \mathrm{O}_{3} \mathrm{~S}$ & 393.42 & 72 & $>265$ & \begin{tabular}{|c|}
$3445,3276,3380,2188$ \\
1663,1722 \\
\end{tabular} & $\begin{array}{c}72.34 \\
(72.50) \\
\end{array}$ & $\begin{array}{c}5.65 \\
(5.52) \\
\end{array}$ & $\begin{array}{l}14.06 \\
(14.1) \\
\end{array}$ \\
\hline $6 f$ & Brown & $\mathrm{C}_{18} \mathrm{H}_{12} \mathrm{~N}_{6} \mathrm{O}_{4} \mathrm{~S}$ & 408.39 & 97 & $>265$ & $\begin{array}{c}3412,3248,3372,2197 \\
1667,1729\end{array}$ & $\begin{array}{l}68.98 \\
(68.88)\end{array}$ & $\begin{array}{c}5.03 \\
(5.10)\end{array}$ & $\begin{array}{c}13.99 \\
(13.89)\end{array}$ \\
\hline $6 g$ & Brown & $\mathrm{C}_{18} \mathrm{H}_{12} \mathrm{BrN}_{5} \mathrm{O}_{2} \mathrm{~S}$ & 442.3 & 63 & 225 & $\begin{array}{c}3431,3218,3342,2191 \\
1665,1727\end{array}$ & $\begin{array}{l}68.98 \\
(69.1) \\
\end{array}$ & $\begin{array}{c}5.03 \\
(5.09)\end{array}$ & $\begin{array}{c}13.99 \\
(13.92) \\
\end{array}$ \\
\hline $7 a$ & Yellow & $\mathrm{C}_{25} \mathrm{H}_{18} \mathrm{~N}_{6} \mathrm{O}_{2} \mathrm{~S}$ & 466.51 & 33 & $>265$ & $\begin{array}{c}3409,3323,2194,1659 \\
1713\end{array}$ & $\begin{array}{l}64.36 \\
(64.44)\end{array}$ & $\begin{array}{c}3.89 \\
(3.94)\end{array}$ & $\begin{array}{c}18.01 \\
(18.11) \\
\end{array}$ \\
\hline $7 b$ & Orange & $\mathrm{C}_{26} \mathrm{H}_{20} \mathrm{~N}_{6} \mathrm{O}_{2} \mathrm{~S}$ & 480.54 & 30 & 217 & $3432,2193,1651,1724$ & $\begin{array}{c}64.98 \\
(65.08)\end{array}$ & $\begin{array}{c}4.20 \\
(4.14)\end{array}$ & $\begin{array}{c}17.49 \\
(17.37)\end{array}$ \\
\hline $7 c$ & Brown & $\mathrm{C}_{26} \mathrm{H}_{20} \mathrm{~N}_{6} \mathrm{O}_{3} \mathrm{~S}$ & 496.54 & 61 & 170 & $\begin{array}{c}3378,3264,2203,1664 \\
1717\end{array}$ & $\begin{array}{l}62.89 \\
(63.01)\end{array}$ & $\begin{array}{c}4.06 \\
(3.97)\end{array}$ & $\begin{array}{c}16.93 \\
(16.87)\end{array}$ \\
\hline $7 d$ & Brown & $\mathrm{C}_{26} \mathrm{H}_{20} \mathrm{~N}_{6} \mathrm{O}_{3} \mathrm{~S}$ & 496.54 & 70 & 160 & $\begin{array}{c}3386,3247,2204,1665 \\
1721 \\
\end{array}$ & $\begin{array}{c}62.89 \\
(62.81) \\
\end{array}$ & $\begin{array}{c}4.06 \\
(4.12) \\
\end{array}$ & $\begin{array}{c}16.93 \\
(16.85) \\
\end{array}$ \\
\hline $7 e$ & Yellow & $\mathrm{C}_{26} \mathrm{H}_{20} \mathrm{~N}_{6} \mathrm{O}_{3} \mathrm{~S}$ & 496.54 & 27 & 224 & $\begin{array}{c}3432,3235,2202,1662 \\
1727 \\
\end{array}$ & $\begin{array}{c}62.89 \\
(62.79) \\
\end{array}$ & $\begin{array}{c}4.06 \\
(4.14) \\
\end{array}$ & $\begin{array}{c}16.93 \\
(16.81) \\
\end{array}$ \\
\hline $7 f$ & Brown & $\mathrm{C}_{25} \mathrm{H}_{17} \mathrm{~N}_{7} \mathrm{O}_{4} \mathrm{~S}$ & 511.51 & 35 & 207 & $\begin{array}{c}3390,3237,2205,1668 \\
1726 \\
\end{array}$ & $\begin{array}{c}58.70 \\
(58.77) \\
\end{array}$ & $\begin{array}{c}3.35 \\
(3.38) \\
\end{array}$ & $\begin{array}{c}19.17 \\
(19.23) \\
\end{array}$ \\
\hline $7 \mathrm{~g}$ & Brown & $\mathrm{C}_{25} \mathrm{H}_{17} \mathrm{BrN}_{6} \mathrm{O}_{2} \mathrm{~S}$ & 545.41 & 28 & 190 & $\begin{array}{c}3403,3236,2203,1665 \\
1726 \\
\end{array}$ & $\begin{array}{c}55.05 \\
(54.93) \\
\end{array}$ & $\begin{array}{c}3.14 \\
(3.11) \\
\end{array}$ & $\begin{array}{c}15.41 \\
(15.53) \\
\end{array}$ \\
\hline $8 a$ & Yellow & $\mathrm{C}_{25} \mathrm{H}_{16} \mathrm{~N}_{6} \mathrm{O}_{2} \mathrm{~S}_{2}$ & 496.56 & 38 & $>265$ & $\begin{array}{c}3384,3175,2191,1661 \\
1731\end{array}$ & $\begin{array}{c}60.47 \\
(60.53)\end{array}$ & $\begin{array}{c}3.25 \\
(3.34)\end{array}$ & $\begin{array}{r}16.92 \\
(16.97)\end{array}$ \\
\hline $8 b$ & Red & $\mathrm{C}_{26} \mathrm{H}_{18} \mathrm{~N}_{6} \mathrm{O}_{2} \mathrm{~S}_{2}$ & 510.59 & 20 & 215 & $\begin{array}{c}3383,3139,2202,1667 \\
1727\end{array}$ & $\begin{array}{c}61.16 \\
(61.02) \\
\end{array}$ & $\begin{array}{c}3.55 \\
(3.68)\end{array}$ & $\begin{array}{c}16.46 \\
(16.32) \\
\end{array}$ \\
\hline $8 c$ & Brown & $\mathrm{C}_{26} \mathrm{H}_{18} \mathrm{~N}_{6} \mathrm{O}_{3} \mathrm{~S}_{2}$ & 526.59 & 94 & 170 & $\begin{array}{c}3403,3172,2205,1669 \\
1730\end{array}$ & $\begin{array}{c}59.30 \\
(59.48) \\
\end{array}$ & $\begin{array}{c}3.45 \\
(3.54) \\
\end{array}$ & $\begin{array}{c}15.96 \\
(16.06) \\
\end{array}$ \\
\hline $8 d$ & Brown & $\mathrm{C}_{26} \mathrm{H}_{18} \mathrm{~N}_{6} \mathrm{O}_{3} \mathrm{~S}_{2}$ & 526.59 & 96 & 177 & $\begin{array}{c}3389,3167,2203,1677 \\
1728 \\
\end{array}$ & $\begin{array}{c}59.30 \\
(59.39) \\
\end{array}$ & $\begin{array}{c}3.45 \\
(3.42) \\
\end{array}$ & $\begin{array}{c}15.96 \\
(16.08) \\
\end{array}$ \\
\hline $8 e$ & Red & $\mathrm{C}_{26} \mathrm{H}_{18} \mathrm{~N}_{6} \mathrm{O}_{3} \mathrm{~S}_{2}$ & 526.59 & 23 & 140 & $\begin{array}{c}3393,3125,2200,1660 \\
1724\end{array}$ & $\begin{array}{c}59.30 \\
(59.26) \\
\end{array}$ & $\begin{array}{c}3.45 \\
(3.58) \\
\end{array}$ & $\begin{array}{c}15.96 \\
(15.88) \\
\end{array}$ \\
\hline $8 f$ & Brown & $\mathrm{C}_{25} \mathrm{H}_{15} \mathrm{~N}_{7} \mathrm{O}_{4} \mathrm{~S}_{2}$ & 541.56 & 46 & 175 & $\begin{array}{c}3386,3152,2207,1659 \\
1730 \\
\end{array}$ & $\begin{array}{c}55.44 \\
(55.37) \\
\end{array}$ & $\begin{array}{c}2.79 \\
(2.82) \\
\end{array}$ & $\begin{array}{c}18.10 \\
(18.21) \\
\end{array}$ \\
\hline $8 g$ & Red & $\mathrm{C}_{25} \mathrm{H}_{15} \mathrm{BrN}_{6} \mathrm{O}_{2} \mathrm{~S}_{2}$ & 575.46 & 36 & 205 & $\begin{array}{c}3426,3174,2208,1662 \\
1725 \\
\end{array}$ & $\begin{array}{c}52.18 \\
(52.27) \\
\end{array}$ & $\begin{array}{c}2.63 \\
(2.80) \\
\end{array}$ & $\begin{array}{c}14.60 \\
(14.78) \\
\end{array}$ \\
\hline $9 a$ & Brown & $\mathrm{C}_{30} \mathrm{H}_{20} \mathrm{~N}_{10} \mathrm{O}_{4} \mathrm{~S}_{2}$ & 648.67 & 77 & 225 & $\begin{array}{c}3331,3216,2204,1662 \\
1733 \\
\end{array}$ & $\begin{array}{c}55.55 \\
(55.47) \\
\end{array}$ & $\begin{array}{c}3.11 \\
(3.24) \\
\end{array}$ & $\begin{array}{r}21.59 \\
(21.11) \\
\end{array}$ \\
\hline $9 b$ & Brown & $\mathrm{C}_{44} \mathrm{H}_{30} \mathrm{~N}_{12} \mathrm{O}_{4} \mathrm{~S}_{2}$ & 854.92 & 29 & $>265$ & $\begin{array}{c}3406,3183,2198,1676 \\
1723 \\
\end{array}$ & $\begin{array}{c}61.82 \\
(62.08) \\
\end{array}$ & $\begin{array}{c}3.54 \\
(3.61) \\
\end{array}$ & $\begin{array}{c}19.66 \\
(19.57) \\
\end{array}$ \\
\hline $9 c$ & Brown & $\mathrm{C}_{44} \mathrm{H}_{26} \mathrm{~N}_{12} \mathrm{O}_{4} \mathrm{~S}_{4}$ & 915.02 & 95 & 240 & $\begin{array}{c}3363,3205,2209,1688 \\
1720\end{array}$ & $\begin{array}{c}57.76 \\
(57.84) \\
\end{array}$ & $\begin{array}{c}2.86 \\
(3.02) \\
\end{array}$ & $\begin{array}{c}18.37 \\
(18.21) \\
\end{array}$ \\
\hline $10 a$ & Brown & $\mathrm{C}_{36} \mathrm{H}_{24} \mathrm{~N}_{10} \mathrm{O}_{4} \mathrm{~S}_{2}$ & 724.77 & 73 & 230 & $\begin{array}{c}3435,3232,2203,1662 \\
1727 \\
\end{array}$ & $\begin{array}{c}59.66 \\
(59.81) \\
\end{array}$ & $\begin{array}{c}3.34 \\
(3.25) \\
\end{array}$ & $\begin{array}{r}19.33 \\
(19.41) \\
\end{array}$ \\
\hline $10 \mathrm{~b}$ & Brown & $\mathrm{C}_{50} \mathrm{H}_{34} \mathrm{~N}_{12} \mathrm{O}_{4} \mathrm{~S}_{2}$ & 931.01 & 50 & 196 & $\begin{array}{c}3392,3192,2197,1678 \\
1722\end{array}$ & $\begin{array}{c}64.50 \\
(64.44)\end{array}$ & $\begin{array}{c}3.68 \\
(3.71)\end{array}$ & $\begin{array}{r}18.05 \\
(18.13) \\
\end{array}$ \\
\hline $10 c$ & Red & $\mathrm{C}_{50} \mathrm{H}_{30} \mathrm{~N}_{12} \mathrm{O}_{4} \mathrm{~S}_{4}$ & 991.11 & 68 & 200 & $\begin{array}{c}3383,3218,2205,1695 \\
1725\end{array}$ & $\begin{array}{l}60.59 \\
(60.71)\end{array}$ & $\begin{array}{c}3.05 \\
(3.18)\end{array}$ & $\begin{array}{c}16.96 \\
(16.84)\end{array}$ \\
\hline
\end{tabular}

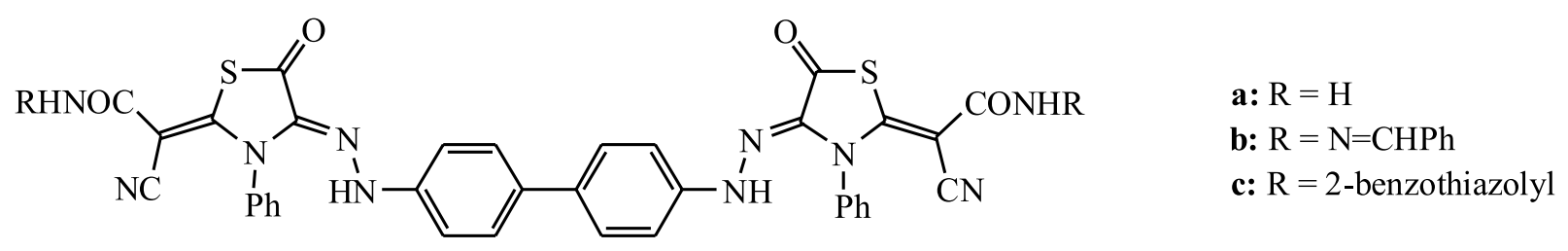


2. The introduction of a nitro group gives a better exhaustion and noticeable depth of color on dye.

3. The bathochromic shift accompanying the substituents in the diazo component was in the following order $\mathrm{H} \rightarrow \mathrm{CH}_{3} \rightarrow \mathrm{OCH}_{3} \sim \mathrm{Br} \rightarrow \mathrm{NO}_{2}$

All the benzothiazolyl dyes $\mathbf{8}$ absorb maximally at longer wavelengths than the corresponding dyes 6 and/or 7. Thus, all the benzothiazolyl dyes $\mathbf{8}$ absorb bathochromically compared with their analogues 6 and 7 as shown in Table 2.

Table 2. Electronic absorption spectra of dyes 6-10 in chloroform

\begin{tabular}{|l|c|c|c|c|c|}
\hline & \multicolumn{5}{|c|}{ Absorption $\lambda_{\max } \mathrm{nm}$} \\
\hline $\begin{array}{l}\text { Dye } \\
\text { No. }\end{array}$ & 6 & 7 & 8 & 9 & 10 \\
\hline a & 408 & 410 & 456 & 408 & 424 \\
\hline b & 410 & 436 & 456 & 412 & 426 \\
\hline c & 420 & 420 & 426 & 424 & 428 \\
\hline d & 424 & 418 & 434 & & \\
\hline e & 422 & 418 & 434 & & \\
\hline f & 428 & 410 & 446 & & \\
\hline g & 420 & 428 & 444 & & \\
\hline
\end{tabular}

\section{Analysis of dyeing performance from aqueous dispersions}

This work describes the application of the synthesized compounds as disperse dyes for dyeing polyester fibers where a range of bright color shades has been obtained as the visual color shades varied from yellow, golden yellow, orange, reddish brown to brown. Generally, variation in color of these dyes results from the alternation in the diazonium and coupling components. The perform- ance is further examined by means of the following techniques:

\section{Color fastness tests}

The synthesized disperse dyes under investigation (6-10) were applied to polyester fibers at the $2 \%$ shade by high-temperature pressure technique $\left(130^{\circ} \mathrm{C}\right)$ and gave generally deep and bright hues, ranging from yellow to brown. The dyes on polyester fibers were evaluated in terms of their fastness properties as shown in Table 3.

a) Fastness to Washing

The rather good fastness properties to washing may be due to 1) the absence of solubilizing groups, which renders solubility, and wash ability of the dye-out of the fibers, 2) the size of the dye molecule is considered relatively big and 3 ) due to the good intrafiber diffusion of the dye molecules inside the fibers.

b) Fastness to Perspiration: (acid and alkaline)

The fastness to acid perspiration is rather satisfactory ranging 4-5. Such results can be expected considering the fact that the prepared arylazothiazole and/or arylazothiophene dyes are relatively stable in acid medium, similar to the conditions used in this test. On the other hand, fastness to alkaline perspiration can be considered good fastness 4-5.

c) Fastness to Rubbing

Fastness to rubbing (wet and dry) is boarder line and this may be attributed to inadequate diffusion of dye molecule into the fibers.

d) Fastness to Sublimation

Table 3. Fastness properties of dyes 6-10 on polyester fibers

\begin{tabular}{|c|c|c|c|c|c|c|c|c|}
\hline Dye & Washing & \multicolumn{2}{|c|}{ Perspiration } & \multicolumn{2}{c|}{ Rubbing } & \multicolumn{2}{c|}{ Sublimation fastness } & Light \\
\hline & (staining) & Acidic & Alkaline & Dry & Wet & $\begin{array}{c}\text { Staining at } \\
180^{\circ} \mathrm{C}\end{array}$ & $\begin{array}{c}\text { Staining at } \\
210^{\circ} \mathrm{C}\end{array}$ & $(80 \mathrm{hr}$.) \\
\hline $6 \mathrm{a}$ & $4-5$ & $4-5$ & $4-5$ & $4-5$ & $4-5$ & $4-5$ & 2 & 4 \\
\hline $6 \mathrm{~b}$ & $4-5$ & $4-5$ & $4-5$ & $4-5$ & $4-5$ & 5 & 2 & 4 \\
\hline $6 \mathrm{c}$ & $4-5$ & 4 & $4-5$ & 3 & 3 & $4-5$ & $4-5$ & 4 \\
\hline $6 \mathrm{~d}$ & $4-5$ & $4-5$ & $4-5$ & $3-4$ & $4-5$ & $4-5$ & $4-5$ & 5 \\
\hline $6 \mathrm{e}$ & $4-5$ & $4-5$ & 4 & 2 & 2 & 4 & 2 & 5 \\
\hline $6 \mathrm{f}$ & $4-5$ & 4 & $4-5$ & $2-3$ & 4 & 5 & 2 & 6 \\
\hline $6 \mathrm{~g}$ & $4-5$ & $4-5$ & $4-5$ & $2-3$ & 3 & $3-4$ & 2 & 4 \\
\hline $7 \mathrm{a}$ & $4-5$ & $4-5$ & $4-5$ & 2 & $2-3$ & $4-5$ & 3 & 4 \\
\hline $7 \mathrm{~b}$ & 4 & $4-5$ & $4-5$ & 2 & 3 & $4-5$ & $2-3$ & 4 \\
\hline $7 \mathrm{c}$ & $4-5$ & $4-5$ & $4-5$ & 4 & 4 & $4-5$ & $4-5$ & 5 \\
\hline $7 \mathrm{~d}$ & $4-5$ & 4 & $4-5$ & 4 & $4-5$ & $4-5$ & $4-5$ & 5 \\
\hline $7 \mathrm{e}$ & $4-5$ & $4-5$ & $4-5$ & 3 & 4 & $4-5$ & $2-3$ & 6 \\
\hline $7 \mathrm{f}$ & $4-5$ & $4-5$ & $4-5$ & 2 & 3 & $4-5$ & 3 & 4 \\
\hline $7 \mathrm{~g}$ & $4-5$ & $4-5$ & $4-5$ & 3 & 4 & $4-5$ & $3-4$ & 4 \\
\hline $8 \mathrm{a}$ & 4 & $4-5$ & $4-5$ & 2 & $2-3$ & 4 & $1-2$ & 4 \\
\hline $8 \mathrm{~b}$ & $4-5$ & $4-5$ & $4-5$ & 2 & 3 & 3 & $1-2$ & 5 \\
\hline $8 \mathrm{c}$ & $4-5$ & $4-5$ & $4-5$ & 2 & 2 & 3 & 2 & 5 \\
\hline $8 \mathrm{~d}$ & $4-5$ & 4 & $4-5$ & 4 & 4 & 4 & 3 & 6 \\
\hline $8 \mathrm{e}$ & 4 & $4-5$ & $4-5$ & 3 & 4 & $2-3$ & $1-2$ & 4 \\
\hline $8 \mathrm{f}$ & $4-5$ & $4-5$ & $4-5$ & 2 & 3 & $3-4$ & 2 & 4 \\
\hline $8 \mathrm{~g}$ & $4-5$ & $4-5$ & $4-5$ & 3 & 4 & 3 & $1-2$ & 4 \\
\hline $9 \mathrm{a}$ & $4-5$ & $4-5$ & $4-5$ & $4-5$ & $4-5$ & $4-5$ & 2 & 5 \\
\hline $9 \mathrm{~b}$ & $4-5$ & $4-5$ & $4-5$ & $4-5$ & $4-5$ & 5 & 2 & 5 \\
\hline $9 \mathrm{c}$ & $4-5$ & $4-5$ & $4-5$ & 3 & 3 & $4-5$ & $4-5$ & 6 \\
\hline $10 \mathrm{a}$ & $4-5$ & $4-5$ & $4-5$ & 2 & $2-3$ & $4-5$ & 3 & 4 \\
\hline $10 \mathrm{~b}$ & $4-5$ & $4-5$ & $4-5$ & 2 & 3 & $4-5$ & $2-3$ & 4 \\
\hline $10 \mathrm{c}$ & $4-5$ & $4-5$ & $4-5$ & 4 & 4 & $4-5$ & $4-5$ & 4 \\
\hline
\end{tabular}


The majority of these dyes were found to have good sublimation fastness 3-4 according to the international Geometric Grey Scale ${ }^{12}$.

e) Fastness to Light

The presence of the electron-withdrawing (nitro or bromo) group in the diazo components improves the light fastness. In most cases, the best light fastness was obtained by the dyes containing a nitro group in the diazo component (e.g. dye 8f).

\section{Color assessment}

The color parameters (table 4) of the dyed polyester fibers were measured using the Gretag Macbeth CE 7000a spectrophotometer. The assessment of color-dyed fibers was made in terms of tristimulus colorimetry. The following CIELAB coordinates are measured, lightness $\left(\mathrm{L}^{*}\right)$, chroma $\left(\mathrm{C}^{*}\right)$, hue angle from 0 o to $360 \mathrm{o}(\mathrm{h}),\left(\mathrm{a}^{*}\right)$ value represents the degree of redness (positive) and greenness (negative) and ( $\left.\mathrm{b}^{*}\right)$ represents the degree of yellowness (positive) and blueness (negative).

A reflectance spectrophotometer (Gretag Macbeth CE 7000a) was used for the colorimetric measurements on the dyed samples. K/S value given by the reflectance spectrometer is directly correlated with the dye concentration on the dye substrate according to the KubelkaMunk equation: $\mathrm{K} / \mathrm{S}=(1-\mathrm{R})^{2} / 2 \mathrm{R}$, where $\mathrm{K}=$ absorbance coefficient, $\mathrm{S}=$ scattering coefficient, $\mathrm{R}=$ reflectance ratio.

The application of the dyes 6-10 on polyester fibers has shown that such dyes have good affinity to polyester fibers. The K/S values in this group of thiazolidin-5-one dyes 6$\mathbf{1 0}$ vary from 0.8 to 12.4 . Dyes 8 which contain the benzothiazolyl moiety are characterized by higher K/S values compared with their analogues $\mathbf{6}$ and $\mathbf{7}$, indicating that the introduction of benzothiazolyl moiety in dyes $\mathbf{8}$ increases the color strength on polyester fibers. The color hue of the dye 8d (substituted by methoxy in the phenylhydrazono group) on polyester fibers is shifted to the greenish direction on the red-green axis as indicated from the negative value of $a^{*}$. These results are in line with the previously reported by Müller ${ }^{13}$ on the effect of the substituent in the dye structure and hue.

\section{CONCLUSION}

A set of 27 disperse dyes 6-10 were synthesized by azo coupling. All of them were investigated for their dyeing characteristics on polyester fibers. The electronic absorption spectra give bright hues from yellow to brown on polyester fibers. The presence of benzothiazolyl moiety in the dyes increases the color strength on polyester fabrics (e.g. dyes 8a-e).The dyed fibers exhibit very good to excellent washing, perspiration and sublimation fastness properties with little variation in the good to excellent rubbing fastness. The degree of levelness after washing is indicative of good penetration and the excellent affinity of these dyes for polyester fiber. This in combination with the ease of preparation makes them particularly valuable.

\section{LITERATURE CITED}

1. Mogilaiah, K., Rao, R.B. \& Sudhakar, G.R. (2001). Synthesis and antibacterial activity of some new 1,8-naphthyridinyl4-thiazolidinones. Indian J. Chem. 40 (4) 336 - 338.
Table 4. Optical measurements of dyes 6-10

\begin{tabular}{|c|c|c|c|c|c|c|}
\hline Dye & $\mathrm{K} / \mathrm{S}$ & $\mathrm{L}$ & $\mathrm{a}$ & $\mathrm{b}$ & $\mathrm{c}$ & $\mathrm{H}$ \\
\hline $6 \mathrm{a}$ & 7.06 & 78.2 & 0.51 & 84.1 & 84.1 & 89.7 \\
\hline $6 \mathrm{~b}$ & 0.80 & 73.7 & 2.75 & 25.3 & 25.5 & 83.8 \\
\hline $6 \mathrm{c}$ & 0.85 & 73.6 & 1.48 & 29.8 & 29.8 & 87.1 \\
\hline $6 \mathrm{~d}$ & 0.85 & 73.9 & 2.55 & 30.5 & 30.6 & 85.2 \\
\hline $6 \mathrm{e}$ & 3.32 & 58.6 & 19.0 & 50.3 & 53.7 & 69.4 \\
\hline $6 \mathrm{f}$ & 3.91 & 72.5 & 6.13 & 63.0 & 63.3 & 84.5 \\
\hline $6 \mathrm{~g}$ & 9.82 & 69.5 & 15.1 & 79.1 & 79.1 & 79.0 \\
\hline $7 \mathrm{a}$ & 3.35 & 74.6 & 7.83 & 55.3 & 55.9 & 81.9 \\
\hline $7 \mathrm{~b}$ & 3.21 & 72.5 & 15.0 & 55.1 & 57.1 & 74.8 \\
\hline $7 \mathrm{c}$ & 2.14 & 71.3 & 9.21 & 47.6 & 48.5 & 79.0 \\
\hline $7 \mathrm{~d}$ & 2.55 & 70.8 & 10.3 & 50.7 & 51.7 & 78.5 \\
\hline $7 \mathrm{e}$ & 2.36 & 68.5 & 17.6 & 49.1 & 52.2 & 70.3 \\
\hline $7 \mathrm{f}$ & 2.96 & 71.6 & 9.27 & 52.8 & 53.6 & 80.1 \\
\hline $7 \mathrm{~g}$ & 1.93 & 74.1 & 9.90 & 56.4 & 57.3 & 80.1 \\
\hline $8 \mathrm{a}$ & 12.1 & 58.0 & 29.7 & 68.2 & 74.4 & 66.5 \\
\hline $8 \mathrm{~b}$ & 12.4 & 70.1 & 20.4 & 86.5 & 88.9 & 76.7 \\
\hline $8 \mathrm{c}$ & 6.42 & 68.4 & 22.3 & 75.2 & 78.4 & 73.2 \\
\hline $8 \mathrm{~d}$ & 3.44 & 49.0 & -6.53 & 69.5 & 69.8 & 95.4 \\
\hline $8 \mathrm{e}$ & 12.0 & 62.9 & 27.9 & 75.9 & 80.0 & 69.8 \\
\hline $8 \mathrm{f}$ & 10.3 & 64.3 & 14.5 & 59.0 & 60.7 & 76.2 \\
\hline $8 \mathrm{~g}$ & 10.8 & 59.2 & 34.5 & 66.3 & 74.8 & 62.5 \\
\hline $9 \mathrm{a}$ & 0.93 & 77.7 & 4.78 & 34.8 & 35.2 & 82.2 \\
\hline $9 \mathrm{~b}$ & 0.87 & 76.5 & 1.88 & 28.9 & 28.9 & 86.3 \\
\hline $9 \mathrm{c}$ & 1.55 & 68.2 & 9.84 & 34.3 & 35.7 & 74.0 \\
\hline $10 \mathrm{a}$ & 4.82 & 64.2 & 22.0 & 60.7 & 64.5 & 70.1 \\
\hline $10 \mathrm{~b}$ & 1.76 & 70.5 & 15.3 & 44.8 & 47.3 & 71.2 \\
\hline $10 \mathrm{c}$ & 3.56 & 58.7 & 29.5 & 47.6 & 56.0 & 58.2 \\
\hline & & & & & & \\
\hline
\end{tabular}

2. Aydogan, F., Öcal, N., Turgut, Z. \& Yolacan, C. (2001). Transformations of aldimines derived from pyrrole-2carbaldehyde: Synthesis of thiazolidino-fused compounds. Bull. Korean Chem. Soc. 22, $476-480$.

3. Cesur, N., Cesur, Z., Ergenc, N., Uzun, M., Kiraz, M., Kasimoglu, O. \& Kaya, D. (1994). Synthes and antifungal activity of some 2-aryl-3-substituted 4-thiazolidinones. Arch. Pharm. (Weinheim) 327, $271-272$.

4. Karali, N. \& Gursoy, A. (1994). Synthesis and antocovulsant activity of some new thiosemicabazone and 4thiazolidone derivatives bearing an isatin moiety. IL Farmaco. $49,819-822$.

5. Gursoy, A. \& Karali, N. (1995). Synthesis and anticonvulsant activity of new acylthiosemicarbazides and thiazolidones. IL Farmaco. 50, 857 - 866.

6. Metwally, M. A., Abdel-Latif, E. \& Amer, F. A. (2001). New 4-arylazo-2- (substituted)-3- phenyl-1,3- thiazolidin-5-ones as disperse dyes part 1. J. Text. Assoc. Nov-Dec, $155-159$.

7. Metwally, M. A., Abdel-Latif, E. \& Amer, F. A. (2002). New 4-arylazo-2-bromo-2-( $\alpha$-bromosubstituted)-3- phenyl1,3- thiazolidin-5-ones dyes for dyeing polyester fabrics part 2. J. Text. Assoc. Nov-Dec, $149-154$.

8. Metwally, M. A., Etman, H. A., Gafer, H. E. \& Khalil, A. M. (2004). New disperse dyes derived 1,3- thiazolidin-4ones and 5- ones for dyeing polester fabrics. Adv. Color. Sci. Technology 7(3), 71 - 78.

9. Standard methods for the determination of the color fastness of textiles and leather. (1990). (5th ed.). Bradford: SDC.

10. Jones, R., Ryan, A. J., Sternhills, S. \& Wright, S. E. (1963). The structures of some 5-pyrazolones and derived 4-arylazo-5-pyrazolones. Tetrahedron, 19, 1497 - 1507.

11. Yasuda, H. (1969). Infrared analysis of 2-pyrazolin-5one derivatives. Appl. Spectroscopy. 23 (1), 22 - 29.

12. SDL. Atlas Ltd. P.O. Box 162, Crown Royal, Shawcross St., Stockport SK1 3JW.

13. Müller, C. (1970). Recent developments in the chemistry of disperse dyes and their intermediate. American Dyestuff reporter March 1970 (37 - 44). 